\title{
Editorial
}

\section{British Journal of Nutrition goes live}

Many readers will already know that the British Journal of Nutrition has been available on the internet ('the Web') since July, as a trial period, free for anyone to look at. From January 1999, this issue, the Journal will be available online only to subscribers. This means that if you have access at present to a printed copy in your institution's library, and your library has registered that subscription with CABI Publishing, you will be able to consult $B J N$ on the Web. The printed version will continue to be produced for the foreseeable future, and institutional subscriptions will now include access to the online version as well as the printed copy.

This development has been under discussion for some time (see Frayn, 1996), and for the past year we (The Nutrition Society and our publishers, CABI Publishing) have been working together to see it to fruition. The Journal is published on one of CABI's servers as part of CABI Publishing's internet resource, Nutrition CABWeb. This means that users will also have ready access both to the other journals published by CABI Publishing for The Nutrition Society (Proceedings of the Nutrition Society, Nutrition Research Reviews and Public Health Nutrition) and to other nutritional journals and abstracts published by CABI. Rights of access to each title will be controlled separately, but together the journals represent an impressive resource in nutritional science. If you have not seen the site yet, please have a look at http://nutrition.cabweb.org/.

The $B J N$ is making this move at just about the same time as most other journals, and for the same reasons (Nature has just announced its own availability on the Web, so we are in august company). What, readers might ask, are the reasons? From the reader's point of view there are many potential advantages. Perhaps most importantly, it will be possible to read the Journal from one's office without having to walk to the library. We are aware that in some large institutions the Journal is taken by one faculty (e.g. agriculture) and is not then easily available to those in, for instance, the faculty of medicine. Provided that the institutional subscription covers all potential readers, that problem should now be resolved. Downloading and printing of individual articles is also easy. But from the reader's point of view, some at least equally important advantages are also under development. It should soon be possible to create links so that, for instance, each reference in the bibliography will itself ultimately be a link to that particular paper or an abstract of it. Emailing messages to authors could become easy by just clicking on the author's email address (this may be seen by authors as a mixed blessing). There is a feeling amongst publishers that journals that do not follow this electronic route will be destined to declining circulations and eventual demise. We believe that these developments will make the Journal even more attractive to authors and readers so that it will retain its position as one of the pre-eminent journals in the field.

The practicalities of access are explained more fully elsewhere in this issue and will be repeated throughout the year, but briefly they are as follows. To register for access your librarian should contact CABI Publishing Customer Services. You will then have access to the full text of articles in the Journal, via Nutrition CABWeb (http:// nutrition.cabweb.org/). Even those without rights of access to the full text can see contents lists and abstracts of the papers free of charge. The full text of papers will appear in two forms: HTML, which is a fairly simple text-like form with embedded illustrations, and PDF, which is a form that looks just like the printed page. If you wish to look at the PDF files you will need to install the Adobe Acrobat Reader (which is available free on the Web): this will then come into operation automatically when you click on the PDF buttons on the contents list. You can then browse through a paper and print as little or as much as you want.

The move to electronic publishing represents a substantial investment in the future of $B J N$, on behalf of The Nutrition Society working with CABI Publishing. We believe it is the way forward. But, as usual, we invite you to let us have your views.

\author{
Keith N. Frayn \\ Editor-in-Chief \\ British Journal of Nutrition \\ Philip Edge \\ Publishing Director \\ CABI Publishing
}

\section{References}

Frayn KN (1996) A time of change at the British Journal of Nutrition. British Journal of Nutrition 75, 1-2. 


\section{The Editorial Staff of the \\ British Journal of Nutrition}

would like to thank all the people who have assisted with reviewing papers during 1998, and would like to wish them and all the British Journal of Nutrition subscribers a very happy New Year. 